\title{
VERMICULITE-BASED CATALYSTS FOR OXIDATION OF ORGANIC POLLUTANTS IN WATER AND WASTEWATER
}

\author{
Agnieszka WĘGRZYN ${ }^{1)}$ *, Lucjan CHMIELARZ ${ }^{1)}$, Paweł ZJEŻDŻALKA ${ }^{1)}$, \\ Magdalena JABLOŃSKA ${ }^{1)}$, Andrzej KOWALCZYK ${ }^{1)}$, Agata ŻELAZNY ${ }^{1)}$, \\ Manuel VÁZQUEZ SULLEIRO ${ }^{2)}$ and Marek MICHALIK ${ }^{3)}$ \\ 1) Jagiellonian University, Faculty of Chemistry, Ingardena 3, 30-060 Kraków, Poland, Phone: 12 6336377, \\ Fax: 126340515 \\ 2) Universidade de Santiago de Compostela, Facultade de Química, 15782 Santiago de Compostela, España, \\ Phone: 981591087, Fax: 981595012 \\ 3) Jagiellonian University, Institute of Geological Sciences, Oleandry 2a, 30-063 Kraków, Phone:12 6632495, \\ Fax: 126332270 \\ *Corresponding author's e-mail: a.m.wegrzyn@uj.edu.pl
}

(Received March 2013, accepted July 2013)

\begin{abstract}
In presented work natural expanded vermiculite was used as a starting material for synthesis of Fe-doped catalysts. Material was modified with increasing amount of $\mathrm{Fe}$ by ion-exchange and precipitation of iron oxide. Composite materials were characterized with respect to their structure (X-ray diffraction, Infrared spectra using Diffuse Reflectance), agglomeration state of $\mathrm{Fe}$ (Ultraviolet-Visible spectra using Diffuse Reflectance) and chemical composition. Activity in $\mathrm{H}_{2} \mathrm{O}_{2}$ decomposition as well as in phenol oxidation was studied in liquid phase at atmospheric pressure and temperature up to $70{ }^{\circ} \mathrm{C}$. It was shown that doping with $\mathrm{Fe}$ increases catalytic activity. However, excess of iron resulted in formation of undesired side-products.
\end{abstract}

KEYWORDS: vermiculite, wastewater, advanced oxidation processes, phenol

\section{INTRODUCTION}

Phenols are frequently encountered organic molecules in contaminated surface water and groundwater. They are characterized by low biodegradability, high Chemical Oxygen Demand (COD) and high toxicity. Industrial wastewater (coke plant sewage, petrochemical industry, paints factories) and municipal wastewater are main sources of phenols. The effective removal of refractory organic pollutants can be achieved using catalytic oxidation of organic pollutants in aqueous solution - one of so called advanced oxidation processes (AOP) (Rokhina and Virkutyte, 2011).

Large group of emerging technologies consist on oxidation processes, such as: wet oxidation, catalytic wet air oxidation, advanced oxidation processes (Busca et al., 2008; Kim and Ihm, 2011; Luck, 1996; Luck, 1999; Biń, 1998; Tomaszewska, 2009). Wet oxidation process is destruction method for waste streams too diluted to incinerate or too concentrated for biological treatment (10-100 g/L of COD) and it may be used at high flow rates. Oxidation by oxygen or air takes place at elevated temperatures (e.g. 125$320{ }^{\circ} \mathrm{C}$ ) and pressures (e.g. 0.5-20 MPa). For that reason those methods are considered as energyconsuming and expensive. Catalytic wet oxidation offers lower energy requirements and higher oxidation efficiencies (Liotta et al., 2009). Operating costs are about half that of non-catalytic process, due to milder reaction conditions and shortening of residence time. Despite high activity of commercial noble metal supported catalysts $(\mathrm{Ru}, \mathrm{Pd}, \mathrm{Pt})$ or homogeneous systems ( $\mathrm{Cu}$ salts), further development of high durability and low cost catalysts is necessary.

Catalytic wet air oxidation of organic compounds (Barbier et al., 2005) was studied on the $\mathrm{CeO}_{2}$-based $\mathrm{Ru}$-, Pd-, Pt-doped catalysts. It was shown that complete conversion of phenol was achieved after $3 \mathrm{~h}$ at $160{ }^{\circ} \mathrm{C}$ and 20 bar of oxygen on the Ru-containing catalysts. Similar results were obtained for the $\mathrm{Ru}-\mathrm{Ce} \gamma-\mathrm{Al}_{2} \mathrm{O}_{3}$-supported catalyst. However in both cases the catalysts were deactivated by the carbonaceous deposition on active sites and phase transformation of the support (Massa et al., 2007). Metal oxide catalysts are less susceptible to poisoning than noble metals and less expensive (Kim and Ihm, 2011). The Cu-based catalysts usually exhibit high activities due to high surface reducibility. Supported catalysts were also studied, because unique pore structure (e.g. mesoporous silicas, activated carbon) or surface morphology (e.g. ceria) increase accessibility of substrates and catalytic activity (Wu et al., 2001; Hocevar et al., 2000; Kim et al., 2007).

Strong oxidants used in the advanced oxidation methods, such as ozone or hydrogen peroxide, offer high conversions at lower temperatures and ambient pressure. Oxidants may be used simultaneously with other chemical compounds $\left(\mathrm{O}_{3}\right.$ and $\left.\mathrm{H}_{2} \mathrm{O}_{2}\right)$ and together with physical factors, such as $\mathrm{UV}, \gamma$ radiation or ultrasounds (Ledakowicz et al., 2001). Presence of a catalyst also improves the efficiency of the process. The most popular combinations of chemical agents are 
$\mathrm{O}_{3}+\mathrm{H}_{2} \mathrm{O}_{2}$ together with Fenton reagent: the mixture of $\mathrm{H}_{2} \mathrm{O}_{2}$ and iron salts. In the latter case, problems with separation of dissolved metal cations may be overcome by application of heterogeneous source of iron.

Oxidation and advanced oxidation processes (AOP) belong to emerging technologies. Although right now application of such a methods on large scale is not possible due to high costs, formation of byproducts and technical constrains, both aforementioned processes present strong advantages (Andreozzi et al., 1999). Oxidation which requires addition of chemicals is rapid and effective process. On the other hand, AOP require little or no consumption of chemicals, but it is effective for recalcitrant pollutants and no sludge is produced during the reaction (Crini, 2006).

In our previous studies it was shown that synthetic anionic clays are very effective in adsorption of phenol and humic acids (Węgrzyn et al., 2006; Węgrzyn et al., 2007), but they show poor mechanical stability in liquid phase. Much more promising seems to be application of silicate minerals in which case acid treatment may be used as an activation procedure (Chmielarz et al., 2010) and on the contrary to zeolites, they can accommodate in the interlayer space even bulky molecules. The following examples show variety of studies conducted on clays and metal oxides in catalytic conversion of some hazardous chemical organic compounds.

Numerous works have been devoted to ironcontaining clays in Fenton and photo-Fenton process. $\mathrm{HO} \cdot$ radicals, basically generated from $\mathrm{H}_{2} \mathrm{O}_{2}$ in the presence of $\mathrm{Fe}^{2+}$ ions, are highly oxidative, nonselective, and able to decompose many organic compounds including refractory pollutants. Incorporation of iron cations or oxides into porous support allows overcoming some drawbacks of the studied process. For example, the $\mathrm{pH}$ range for application of the Fenton is quite narrow, in the range 2.5-4.0 (Navalon et al., 2010). Additional separation steps in order to remove the iron sludges from the treated water after the reaction and neutralization step is necessary. It was observed that heterogeneous nanosize solid catalyst can accelerate the reaction rate (Soon and Hameed, 2011). Active centers are dispersed on surface in the form of iron oxides, polymeric iron species, and iron ions. On the contrary to homogeneous reaction, broad $\mathrm{pH}$ range may be used. Sludge treatment is not necessary or only minimal ferric hydroxide is formed due to leaching of the active components into the bulk solution. Catalysts loss is limited due to anchoring to the surface of porous solid materials. Recovery is easy and recycling is guaranteed.

Clay-based catalysts are characterized with high activity in the wide range of $\mathrm{pH}(3.0-9.5)$. Leaching of the active phases may occur after the formation of acidic intermediates in solution. Catalytic activity is enhanced under visible light irradiation; however it takes longer than in homogeneous solution to mineralize organic pollutants. In the clay-based catalysts iron occurs naturally or may be added in synthetic clays in controlled amounts. Acid activation can minimize leaching. High efficiency remains for many runs of catalytic reaction and regeneration.

The catalysts used in the Fenton-like system are natural iron-bearing earth materials, such as goethite, hematite, magnetite or ferrihydrite (Xu et al., 2009; Matta et al., 2007). Another interesting mineral of tourmaline group, shorl, was proposed (Xu et al., 2009). It exhibits unique properties, such as pyroelectricity and piezoelectricity. Tourmaline can generate an electrostatic charge, when a specimen is put under a tiny pressure or temperature change. Interesting results were also obtained for nanoparticulate zero-valent iron (Xu and Wang, 2011).

Typically montmorillonites, saponites, laponites or zeolites are doped with different Fe-species (Navalon et al., 2010; Dukkancı et al., 2010; Iurascu et al., 2009; Feng et al., 2006; Ramirez et al., 2007; Galeano et al., 2011). Iron may be introduced via ionexchange, impregnation (Ramirez et al., 2007), intercalation of polycations (Iurascu et al., 2009; Tabet et al., 2006) or with multicomponent pillars (Carriazo et al., 2005). The most frequent applications of Fenton-like process are removal of dyes, phenols, organic acids, pesticides, endocrine disrupting compounds (Garrido-Ramírez et al., 2010).

For example, recently the vermiculite-based iron-pillared catalysts have been designed for photocatalytic degradation of azo dye (Chen et al., 2010). Under optimal conditions, at $30^{\circ} \mathrm{C}, \mathrm{pH}$ equal 3, oxidant concentration $3.93 \mathrm{mM}$, catalysts loading $0.5 \mathrm{~g} / \mathrm{L}, 98.7 \%$ decoloration and $54.4 \%$ reduction of TOC was obtained in a solution of reactive brilliant orange $\mathrm{X}-\mathrm{GN}(100 \mathrm{mg} / \mathrm{L})$ after 75 minutes of UV irradiation. It was also shown that the catalyst exhibited long-term stability.

Up till now studies on materials like vermiculites are not as comprehensive or numerous as in the case of bentonites or metal oxides. The aim of presented work was preparation of a series of vermiculite-based catalysts doped with iron. Basic physico-chemical characterization was performed using X-ray diffraction, Diffuse Reflectance Infrared spectroscopy, Diffuse Reflectance Ultraviolet-Visible spectroscopy and analysis of $\mathrm{Fe}$ content in obtained materials. Oxidation of model pollutant (phenol) using $\mathrm{H}_{2} \mathrm{O}_{2}$ was studied. The influence of $\mathrm{Fe}$ content as well as parameters of catalytic test on activity of modified vermiculites was determined.

\section{EXPERIMENTAL}

\subsection{MATERIALS}

Commercial expanded vermiculite from South Africa (sample S0), fraction size $1 \mathrm{~mm}$, was provided 


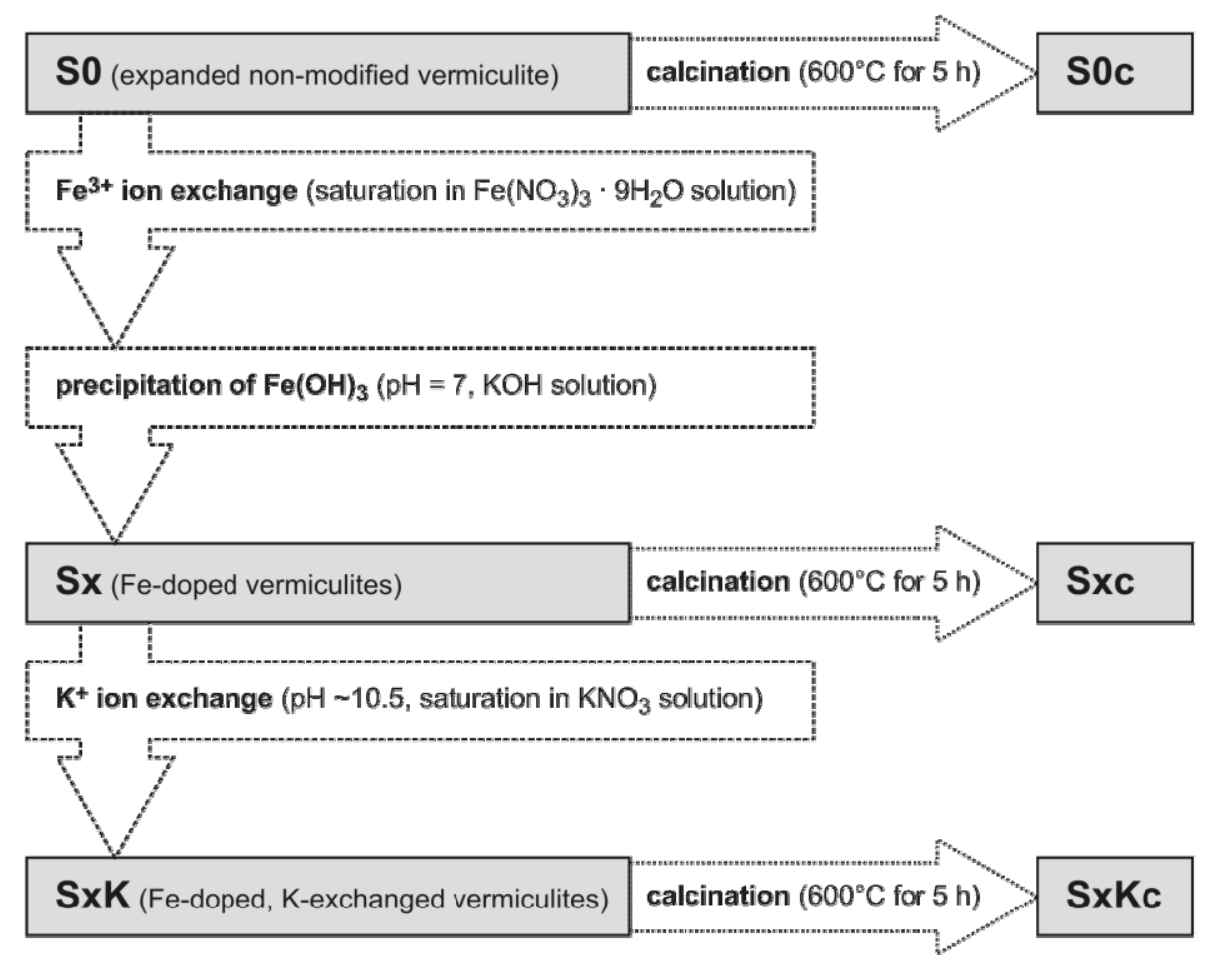

Fig. 1 Preparation of vermiculite-based catalysts.

by Romico Polska Sp. z o.o. A series of catalysts was prepared according to 4 steps procedure:

- $20 \mathrm{~g}$ of vermiculite was suspended in $600 \mathrm{~mL}$ of distilled water and then $400 \mathrm{~mL}$ of $\mathrm{Fe}\left(\mathrm{NO}_{3}\right)_{3}$ $9 \mathrm{H}_{2} \mathrm{O}$ (p.a., POCh) solution of increasing $\mathrm{Fe}$ concentration in each synthesis, was added stepwise; during ion exchange suspension was stirred continuously for $2 \mathrm{~h}$,

- under constant stirring $\mathrm{pH}$ of the mixture was raised up to 7 by stepwise addition of $0.1-0.4 \mathrm{M}$ $\mathrm{KOH}$ (p.a., POCh) depending on concentration of iron salt used in previous step; crystallization was continued for next 30 minutes (samples Sx),

- in each synthesis part of the filtered precipitate was submitted to additional ion exchange: interlayer $\mathrm{Fe}^{3+}$ cations were replaced by $\mathrm{K}^{+} ; 0.1 \mathrm{M}$ solution of $\mathrm{KNO}_{3}$ (p.a., POCh) was added slowly and suspension was stirred again for $2 \mathrm{~h}$ at $\mathrm{pH} \sim 10.5$ (samples $\mathrm{SxK}$ ),

- in the last step, after filtering, washing with distilled water and drying at room temperature, small amount of each catalyst was calcined at $600{ }^{\circ} \mathrm{C}$ for $5 \mathrm{~h}$ (samples Sxc and SxKc).

As reference samples were used expanded nonmodified vermiculite ( $\mathrm{S} 0$ ) and iron oxide precipitated after the reaction of $\mathrm{Fe}\left(\mathrm{NO}_{3}\right)_{3} \cdot 9 \mathrm{H}_{2} \mathrm{O}$ with solution of $\mathrm{KOH}$ (the $\mathrm{pH}$ after the precipitation reached value 7) (sample S6).

Summary of the preparation procedure of vermiculite-based catalysts was illustrated in Figure 1.

\subsection{METHODS OF CHARACTERISATION}

The structure of as prepared and calcined samples was studied using a powder diffractometer (Bruker, D2 PHASER) equipped with $\mathrm{CuK}_{\alpha}$ radiation source. Infrared spectra of the samples diluted with $\mathrm{KBr}$ were recorded using diffused reflectance technique (Nicolet 6700 FT-IR, Thermo Scientific). The coordination and aggregation of iron present in the catalysts was studied by UV-Vis-DRS spectroscopy. The measurements were performed in the range of $200-900 \mathrm{~nm}$ with a resolution of $2 \mathrm{~nm}$ using an Evolution 600 (Thermo) spectrophotometer. Content of iron was measured using spectrophotometric technique at wavelength $\lambda 510 \mathrm{~nm}$ (Thermo SCIENTIFIC EVOLUTION 220) as a complex with 1,10-phenanthroline after leaching of metal cations in $6 \mathrm{M} \mathrm{HCl}$. Physico-chemical characterisation was also performed for selected spent catalysts (sample names $\mathrm{Sx}(\mathrm{r}), \mathrm{SxK}(\mathrm{r}), \mathrm{Sxc}(\mathrm{r})$, $\mathrm{SxKc}(\mathrm{r}))$.

\subsection{CATALYTIC TESTS}

Catalytic tests were carried out in a roundbottom flask equipped with reflux condenser (continuously stirred batch reactor). In each standard phenol (PhOH) oxidation test $150 \mathrm{~mL}$ of stock solution containing phenol $(2.5 \mathrm{~g} / \mathrm{L})$ was mixed with $5 \mathrm{~mL}$ of oxidant solution $\left(30 \% \mathrm{H}_{2} \mathrm{O}_{2}\right.$, p.a. POCh) and total volume was made up to $175 \mathrm{~mL}$ with distilled water. Final concentration $-2 \mathrm{~g} / \mathrm{L}$ of phenol was used with the aim to simulate raw wastewater from coking plant. For selected reactions solution of hydrogen 
peroxide was added stepwise: $0.5 / 1 \mathrm{~mL}$ every $10 / 15$ minutes until total volume of $5 \mathrm{~mL}$ was achieved. In tests of hydrogen peroxide decomposition phenol solution was replaced with water. Reaction was carried out for $2 \mathrm{~h}$ in the presence of $300 \mathrm{mg}$ of the catalyst. $\mathrm{H}_{2} \mathrm{O}_{2}$ decomposition and $\mathrm{PhOH}$ oxidation reactions were studied at atmospheric pressure and temperature equal $\mathrm{T}=30,50,70{ }^{\circ} \mathrm{C}$. Phenol concentration was measured spectrophotometrically (Thermo SCIENTIFIC EVOLUTION 220) as a complex with 4-aminoantipyrine. For determination of $\mathrm{H}_{2} \mathrm{O}_{2}$ concentration titration with thiosulfate was used. Changes of $\mathrm{pH}$ were monitored throughout each experiment. Conversion (X [\%]) of model pollutant (phenol) and oxidant $\left(\mathrm{H}_{2} \mathrm{O}_{2}\right)$ was calculated according to equation (1):

$$
X=\frac{C_{0}-C}{C_{0}} \cdot 100 \%
$$

in which $\mathrm{C}_{0}$ is starting concentration and $\mathrm{C}$ is concentration at given reaction time of phenol or hydrogen peroxide.

\section{RESULTS AND DISCUSSION}

\subsection{CHARACTERISATION OF THE CATALYSTS}

Fresh catalysts, as prepared, before and after potassium ion exchange (Sx-SxK) were characterized with similar content of iron. This fact may be easily explained taking into account conditions in that step $\mathrm{pH}$ was close to 10 and precipitation of iron oxide/hydroxide may be expected. The amount of iron in the samples before ion exchange is presented in Table 1. The amount of iron naturally observed in vermiculite is slightly higher than $6 \mathrm{wt} . \%$ and iron is present mainly in phyllosilicate layer. It cannot be

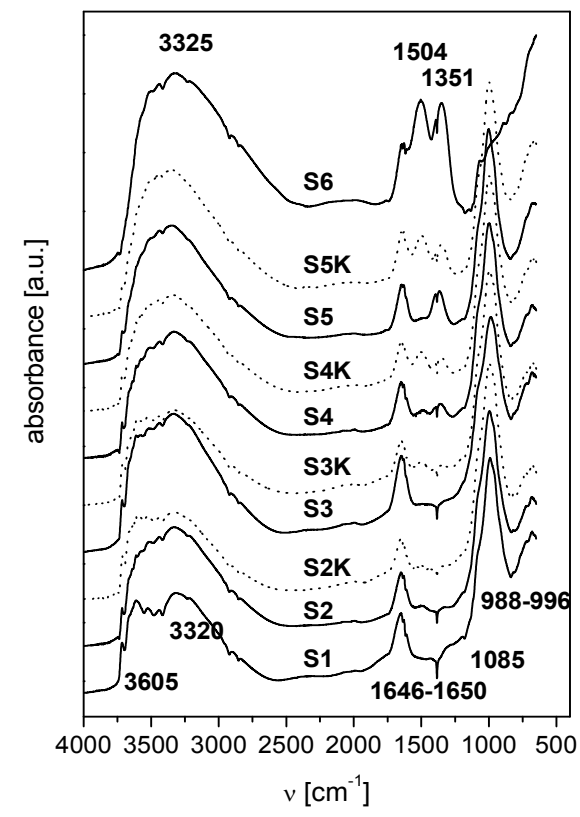

Fig. 2 DRIFT spectra of as prepared catalysts without $(\mathrm{Sx})$ and with $(\mathrm{SxK})$ potassium ion exchange.
Table 1 Fe content in as prepared vermiculite-based catalysts.

\begin{tabular}{c|c|c}
\hline sample name & {$\left[\mathrm{Fe}_{\text {total }} \text { wt.\% }\right]^{*}$} & {$\left[\mathrm{Fe}_{\text {doped }} \mathrm{wt} . \%\right]^{* *}$} \\
\hline S0 & 6.02 & 0 \\
S1 & 7.14 & 1.65 \\
S2 & 8.57 & 3.24 \\
S3 & 11.28 & 6.28 \\
S4 & 16.26 & 11.82 \\
S5 & 24.71 & 21.14 \\
S6 & 69.94 & n.a. \\
\hline
\end{tabular}

* - total Fe content,

** - Fe introduced in doping process.

also excluded however that some $\mathrm{Fe}$ cations are located in interlayer space. After Fe doping increasing amount of iron (between 1.65 and 21.14 wt.\% of Fe) could be deposited on the vermiculite support as hydroxide/oxide clusters or intercalated into interlayer galleries in form of $\mathrm{Fe}^{3+}$ cations.

No significant difference was also observed in DRIFT (Fig. 2.) and UV-Vis-DRS (Fig. 3.) spectra between the samples before and after ion exchange. The broad bands in infrared spectra around 3600$3300 \mathrm{~cm}^{-1}$ were assigned as stretching vibrations of $-\mathrm{OH}$ groups in the mineral structure or water molecules. Two bands dominate in the starting material (3605 and $3320 \mathrm{~cm}^{-1}$ ) and upon Fe-doping they become broader and finally overlap in one peak which should indicate higher heterogeneity of $-\mathrm{OH}$ species. Bending vibrations of interlayer and adsorbed water molecules result in formation of band around $1646-1650 \mathrm{~cm}^{-1}$. Several other bands characteristic for aluminosilicate structure vibrations appear: band at 1085 and $988-996 \mathrm{~cm}^{-1}$ can be assigned to $\mathrm{Si}-\mathrm{O}-\mathrm{Si}$

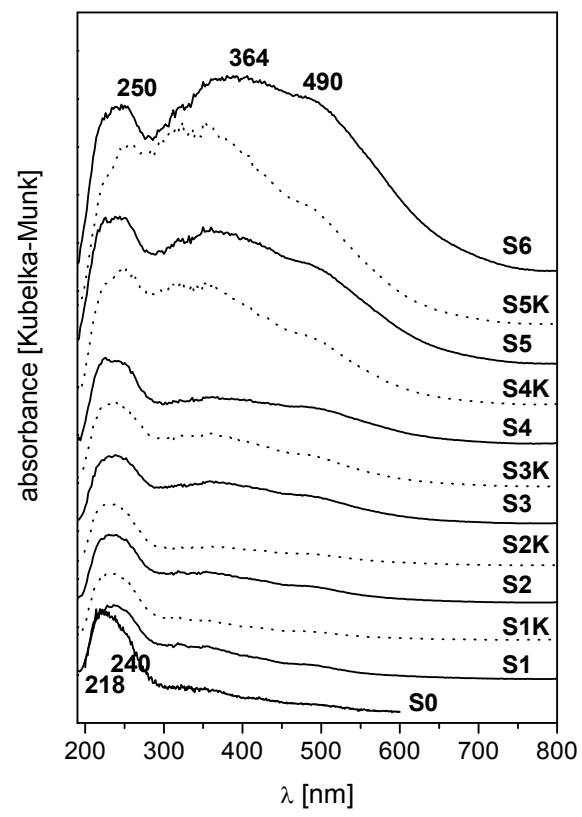

Fig. 3 UV-Vis-DRS spectra of as prepared catalysts without $(\mathrm{Sx})$ and with $(\mathrm{SxK})$ potassium ion exchange. 


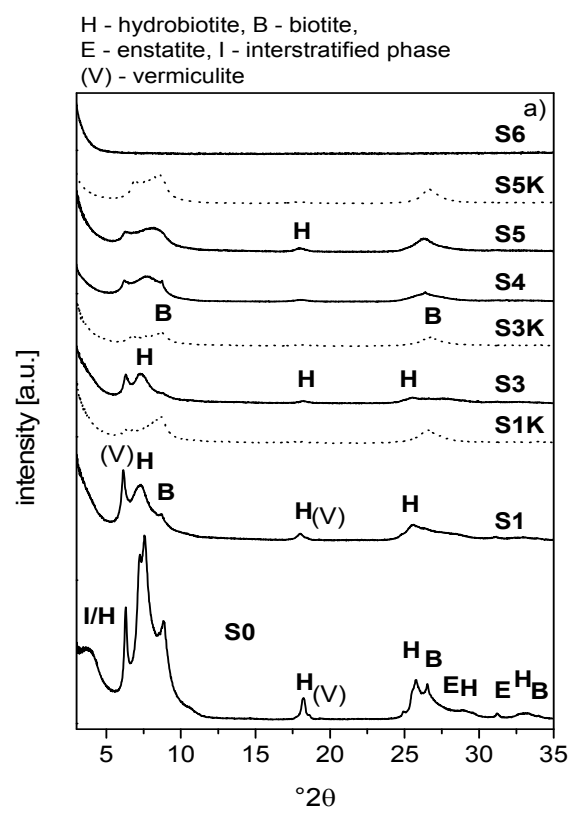

Fig. 4 XRD patterns of

a) as prepared catalysts without (Sx) and with (SxK) potassium ion exchange, b) after calcination ( $\mathrm{Sxc}, \mathrm{SxKc})$, c) iron oxide/hydroxide reference sample before and after calcination (S6, S6c).
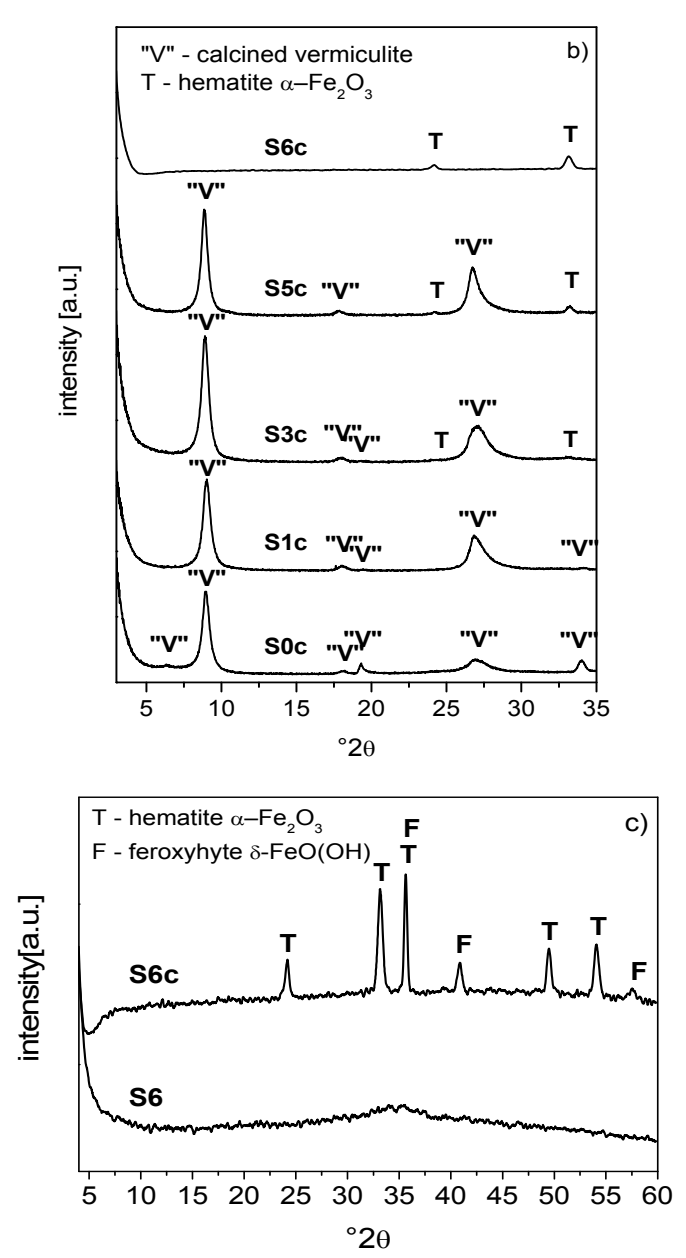

Chmielarz et al., 2010, Chmielarz et al., 2012). After calcination (selected results shown in section 3.5., Fig. 9) all peaks become more intense. It was also observed that both peaks assigned as small clusters and bulk iron oxide are shifted to higher wavelengths: from $360-364$ to $385-390 \mathrm{~nm}$ and from 490 to $520 \mathrm{~nm}$, respectively.

XRD results (Fig. 4a) indicate that fresh materials are characterized with similar phase composition, however basal reflections positions are strongly influenced by cations introduced during synthesis. In the case of all samples two main phases of hydrobiotite (peaks of high intensity at 1.223, $0.349,0.491,0.272 \mathrm{~nm}$ ) (Downs, 2006) and biotite (peaks of high intensity at 1.01, 0.337, $0.266 \mathrm{~nm}$ ) (Downs, 2006) were identified, although it seems that hydrobiotite is dominating in the samples without $\mathrm{K}^{+}$ ion exchange. On the contrary, biotite is the main phase after exchange with potassium. Additional peaks at $0.317,0.288,0.254 \mathrm{~nm}$ could be related to enstatite (Downs, 2006); others at $\sim 1,0.457,0.261$, $0.257 \mathrm{~nm}$ could be related to vermiculite (Downs, 2006), however in expanded material these peaks might also correspond with mica-like structure (probably muscovite) (Marcos et al., 2009; Marcos et al., 2010). clusters and above $400 \mathrm{~nm}$ - bulk $\mathrm{Fe}_{2} \mathrm{O}_{3}$ oxide (Chmielarz et al., 2008, Chmielarz et al., 2009, peak at $218 \mathrm{~nm}$ is more intense than peak at $240 \mathrm{~nm}$. Upon $\mathrm{Fe}$ doping bands assigned to octahedra coordination become more intense and are shifted to higher wavelengths $(250 \mathrm{~nm})$. Increases also the intensity of bands about $360 \mathrm{~nm}$ related to small $\mathrm{Fe}_{\mathrm{x}} \mathrm{O}_{\mathrm{y}}$ 
Table 2 Interlayer distance of Fe-modified vermiculite-based catalysts.

\begin{tabular}{|c|c|c|c|c|c|c|}
\hline sample name & $\mathrm{d}[\mathrm{nm}]$ & $\mathrm{d}[\mathrm{nm}]$ & $\mathrm{d}[\mathrm{nm}]$ & $\mathrm{d}[\mathrm{nm}]$ & $\mathrm{d}[\mathrm{nm}]$ & $\left(\mathrm{d}[\mathrm{nm}]^{*}\right)$ \\
\hline S0 (S0c*) & 2.37 & 1.40 & 1.22 & 1.17 & 1.00 & $(0.988)$ \\
\hline S1 (S1c*) & 2.47 & 1.44 & 1.21 & & 1.02 & $(0.981)$ \\
\hline $\mathrm{S} 1 \mathrm{~K}$ & & 1.37 & & $(\ldots)$ & 1.01 & \\
\hline S3 (S3c*) & 2.31 & 1.40 & 1.21 & & 1.00 & $(0.993)$ \\
\hline S3K & & 1.30 & & & 1.02 & \\
\hline $\mathrm{S} 4$ & & 1.43 & & 1.15 & 1.01 & \\
\hline \multirow[t]{3}{*}{ S5 (S5c*) } & & 1.40 & & $(\ldots)$ & 1.09 & $(0.996)$ \\
\hline & & $\begin{array}{l}\text { dominating in } \\
\text { Sx samples }\end{array}$ & & & $\begin{array}{l}\text { dominating in } \\
\text { SxK samples }\end{array}$ & $\begin{array}{l}\text { calcined } \\
\text { samples }\end{array}$ \\
\hline & $\begin{array}{l}\text { inter- } \\
\text { stratification }\end{array}$ & $\begin{array}{c}2 \text { layers } \\
\text { of water } \\
\mathrm{Mg}^{2+} / \mathrm{Fe}^{3+}\end{array}$ & $\begin{array}{l}\text { inter- } \\
\text { stratification }\end{array}$ & $\begin{array}{c}1 \text { layer } \\
\text { of water } \\
\mathrm{Mg}^{2+} / \mathrm{Fe}^{3+}\end{array}$ & $\begin{array}{c}0 \text { layers } \\
\text { of water } \\
\mathrm{K}^{+} \text {in non } \\
\text { calcined } \\
\text { samples }\end{array}$ & $\begin{array}{l}\text { mica-like } \\
\text { structure }\end{array}$ \\
\hline
\end{tabular}

* - results for calcined samples

Table 2 presents interlayer distances calculated for all obtained samples. In case of the samples without $\mathrm{K}^{+}$ion exchange one should expect that interlayer space is occupied mainly by $\mathrm{Fe}^{3+}$ cations. It cannot be excluded that original cations such as $\mathrm{Mg}^{2+}$ were not removed completely. It was reported before (Helsen, 1975; Argüelles et al., 2011) that ion exchange of the $\mathrm{Mg}^{+2}$ cations with $\mathrm{Fe}^{3+}$ results in small decrease of d-spacings (from 1.44 to $1.42 \mathrm{~nm}$ ) related both to changes in the interaction between interlayer $\mathrm{Fe}$ ions and the cations in the octahedral layers as well as changes in the configuration of the water molecules. However, in both cases calculated interlayer distances are related to 2 layers of water and are dominating in the series Sx. Heterogeneity of cationic composition may result in appearance of additional shoulder in the range of $7.0-7.5^{\circ} 2 \theta$. On the other hand, potassium exchanged samples are characterized with lower interlayer distances usually assigned as 0 layers of water molecules and typically associated with the presence of interlayer $\mathrm{K}^{+}$ (Chmielarz et al., 2010, Chmielarz et al., 2012). Interstratified phase was detected only at low $\mathrm{Fe}$ loadings in the samples S0-S3. After calcination (Fig. 4.b) the main phase is more uniform in all samples and was indicated as calcined vermiculite. In this case the interlayer distances should be described as, most probably, mica-like structure (Marcos et al., 2009; Marcos et al., 2010).

Iron oxide, which is component of composite catalysts, is characterized with completely amorphous structure. After calcination at $600^{\circ} \mathrm{C}$ two phases were identified in the reference sample S6c (Fig. 4c): hematite and feroxyhyte. Traces of those phases were identified only in the samples with higher Fe doping after calcination: S3c-S5c.

\subsection{THE INFLUENCE OF TEMPERATURE ON SUBSTRATE CONVERSION}

Results of catalytic tests, presented in Figure 5, confirm that catalytic activity in both studied reactions
$\left(\mathrm{H}_{2} \mathrm{O}_{2}\right.$ decomposition and phenol oxidation using $\mathrm{H}_{2} \mathrm{O}_{2}$ ) strongly depends on temperature. It was shown that samples doped with iron are active in decomposition of hydrogen peroxide (Fig. 5a). However time of $50 \%$ conversion (Table 3.) is shorter for the samples without $\mathrm{K}^{+}$ion exchange. It cannot be excluded that $\mathrm{Fe}^{3+}$ cations are released from interlayer spaces of the samples and play role of catalysts.

Similar conversions of $\mathrm{H}_{2} \mathrm{O}_{2}$ playing role of oxidant in oxidation of phenol (Fig. 5b) were obtained for the sample S4. Although it should be noted that in the case of all studied catalysts, due to the presence of second substrate (phenol), the time necessary for $50 \%$ conversion is significantly longer. The non-modified sample S0 is characterized with very low conversions at temperatures 30 and $50{ }^{\circ} \mathrm{C}-$ not higher than $10 \%$. Low conversions of phenol (Fig. 5c) were also measured for the sample $\mathrm{S} 0$ at temperatures below $70{ }^{\circ} \mathrm{C}$ and $\mathrm{S} 4$ at $30{ }^{\circ} \mathrm{C}$. Another interesting observation, shorter time necessary for $50 \%$ phenol conversion than $\mathrm{H}_{2} \mathrm{O}_{2}$, may be explained by the reaction mechanism. $\mathrm{OH} \bullet$ radicals are obtained on the catalyst from $\mathrm{H}_{2} \mathrm{O}_{2}$ and they initiate chain reactions of organic radicals. From that point phenol is converted in reactions with radicals until those reactions are terminated (Bielicka-Daszkiewicz, 2008; Rivas et al., 1999; Magario et al., 2012). It should be also taken into account that hydrogen peroxide was used with excess with respect to organic substrate.

\subsection{THE INFLUENCE OF IRON CONTENT AND POTASSIUM EXCHANGE ON PHENOL CONVERSION}

Selected results of catalytic tests carried out at $70{ }^{\circ} \mathrm{C}$ over iron doped vermiculite-based materials with increasing amount of $\mathrm{Fe}$ are presented in Figure 6. In all tests it was shown that conversion of phenol as well as $\mathrm{H}_{2} \mathrm{O}_{2}$ strongly depends on Fe content. In the case of non-calcined materials without $\mathrm{K}^{+}$ ion exchange (Sx series) the higher Fe doping the shorter time of $\alpha 50 \%$ (Table 4). Within 60 minutes 

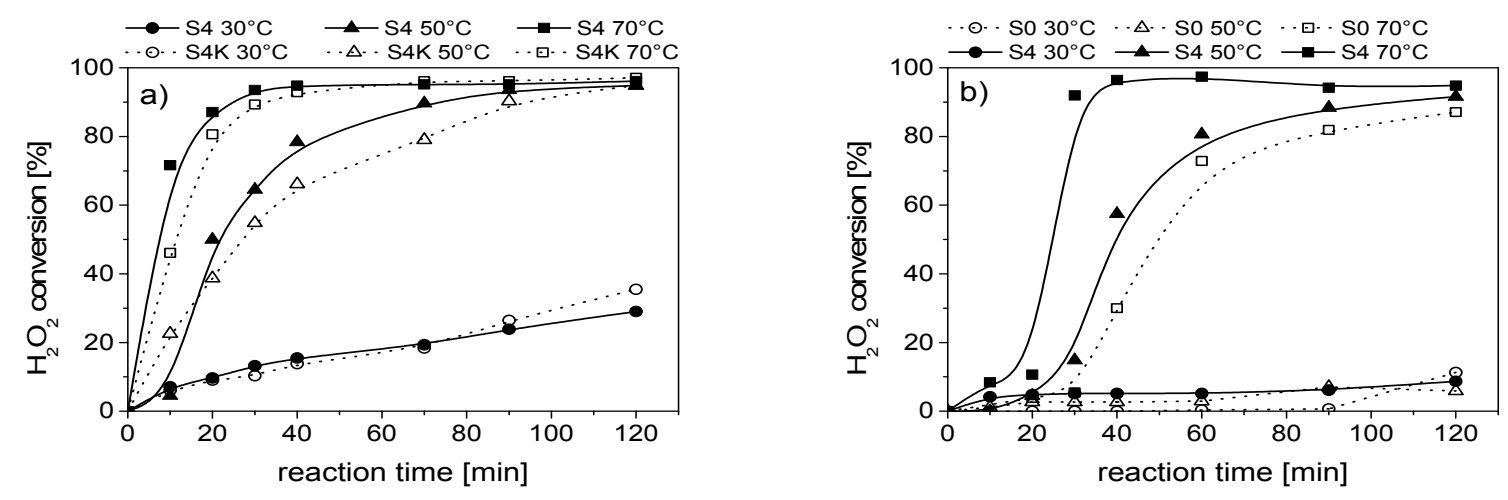

Fig. 5 The influence of the reaction temperature on substrate conversion in reaction of

a) $\mathrm{H}_{2} \mathrm{O}_{2}$ decomposition;

b) and c) phenol oxidation using $\mathrm{H}_{2} \mathrm{O}_{2}$, over vermiculite-based Fe-doped catalysts.

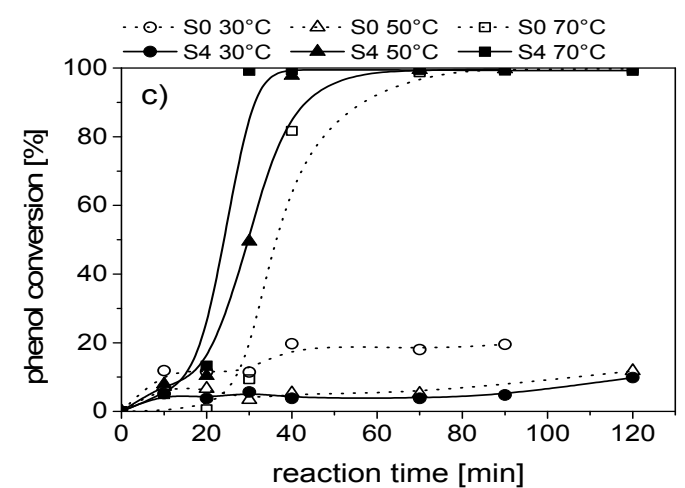

Table 3 Time of 50\% conversion (time $\alpha 50 \%$ ) of substrates in decomposition of $\mathrm{H}_{2} \mathrm{O}_{2}$ and phenol oxidation over vermiculite-based Fe-doped catalysts.

\begin{tabular}{r|c|c|c|c|c|c}
\hline reaction & \multicolumn{2}{|c|}{$\mathrm{H}_{2} \mathrm{O}_{2}$ decomposition } & \multicolumn{4}{c}{ phenol oxidation } \\
\hline substrate & $\mathbf{H}_{2} \mathbf{O}_{2}$ & $\mathrm{H}_{2} \mathrm{O}_{2}$ & $\mathrm{H}_{2} \mathrm{O}_{2}$ & $\mathrm{PhOH}$ & $\mathbf{H}_{\mathbf{2}} \mathbf{O}_{\mathbf{2}}$ & PhOH \\
\hline catalyst & $\mathbf{S 4}$ & $\mathrm{S} 4 \mathrm{~K}$ & $\mathrm{~S} 0$ & $\mathrm{~S} 0$ & $\mathbf{S 4}$ & $\mathbf{S 4}$ \\
\hline temperature & time $\alpha 50 \%$ & time $\alpha 50 \%$ & time $\alpha 50 \%$ & time $\alpha 50 \%$ & time $\alpha 50 \%$ & time $\alpha 50 \%$ \\
{$\left[{ }^{\circ} \mathrm{C}\right]$} & {$[\mathrm{min}]$} & {$[\mathrm{min}]$} & {$[\mathrm{min}]$} & {$[\mathrm{min}]$} & {$[\mathrm{min}]$} & {$[\mathrm{min}]$} \\
\hline 30 & - & - & - & - & - & - \\
50 & $\mathbf{2 2}$ & 28 & - & - & $\mathbf{4 0}$ & $\mathbf{3 0}$ \\
70 & $\mathbf{7}$ & 12 & 50 & 37 & $\mathbf{2 5}$ & $\mathbf{2 4}$ \\
\hline
\end{tabular}

Table 4 The influence of iron content on substrate conversion in phenol oxidation over vermiculite-based Fedoped catalysts - time of $50 \%$ conversion.

\begin{tabular}{c|c|c|c|c|c|c|c|c}
\hline $\begin{array}{r}\text { catalysts } \\
\text { series }\end{array}$ & \multicolumn{2}{|c|}{$\mathrm{Sx}$} & \multicolumn{2}{c|}{$\mathrm{Sxc}$} & \multicolumn{2}{c|}{$\mathrm{SxK}$} & \multicolumn{2}{c}{$\mathrm{SxKc}$} \\
\hline substrate & $\mathrm{H}_{2} \mathrm{O}_{2}$ & $\mathrm{PhOH}$ & $\mathrm{H}_{2} \mathrm{O}_{2}$ & $\mathrm{PhOH}$ & $\mathrm{H}_{2} \mathrm{O}_{2}$ & $\mathrm{PhOH}$ & $\mathrm{H}_{2} \mathrm{O}_{2}$ & $\mathrm{PhOH}$ \\
\hline & time & time & time & time & time & time & time & time \\
catalyst & $\alpha 50 \%$ & $\alpha 50 \%$ & $\alpha 50 \%$ & $\alpha 50 \%$ & $\alpha 50 \%$ & $\alpha 50 \%$ & $\alpha 50 \%$ & $\alpha 50 \%$ \\
number & {$[\mathrm{min}]$} & {$[\mathrm{min}]$} & {$[\mathrm{min}]$} & {$[\mathrm{min}]$} & {$[\mathrm{min}]$} & {$[\mathrm{min}]$} & {$[\mathrm{min}]$} & {$[\mathrm{min}]$} \\
\hline 0 & 50 & 36 & - & - & 50 & 36 & - & - \\
1 & 46 & 33 & - & - & 48 & 36 & - & - \\
2 & 41 & 34 & - & 104 & n.d. & n.d. & n.d. & n.d. \\
3 & 37 & 32 & $\mathbf{6 8}$ & $\mathbf{2 8}$ & 25 & 13 & 106 & 87 \\
4 & 25 & 24 & 102 & 77 & 10 & $\mathbf{5}$ & 113 & 95 \\
5 & 15 & $\mathbf{1 4}$ & - & 101 & $\mathbf{5}$ & $\mathbf{5}$ & $\mathbf{1 0 3}$ & $\mathbf{8 2}$ \\
6 & $\mathbf{1 1}$ & 24 & - & - & n.a. & n.a. & n.a. & n.a. \\
\hline
\end{tabular}

complete conversion of phenol is achieved over all tested catalysts with the exception of S6 - pure iron oxide (Fig. 6a). Surprisingly for that catalyst reaction is not fully effective and final phenol conversion is equal $91 \%$. Similar result was obtained for calcined catalyst in studied series (S6c). After fast increase up to $30 \%$ conversion is stable and increases to $39 \%$ after 120 minutes of the reaction. Induction phase was also observed for the calcined samples S2c, S4c, S5c (Fig. 6b). On the contrary the sample S3c was very active and total conversion of phenol was observed between 70 and 90 minutes. Nevertheless calcined samples were less active than as prepared catalysts.

In the series of the samples submitted to ion exchange with potassium and without calcination (Fig. 6c) high phenol conversion was achieved in 

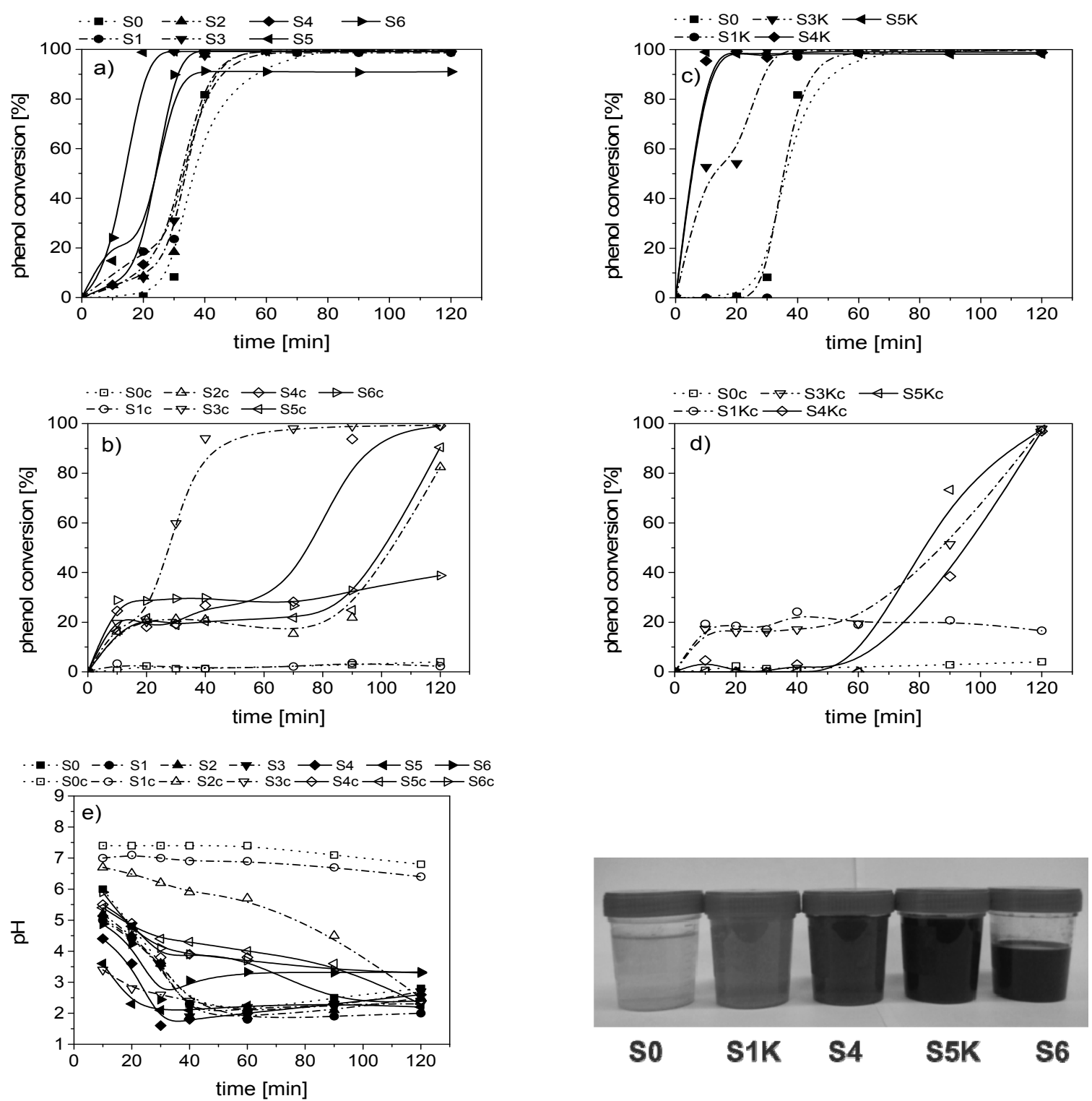

Fig. 6 a) and b) The influence of iron content and calcination on phenol conversion over catalysts without potassium exchange, $\mathrm{Sx}$ and $\mathrm{Sxc}$;

c) and d) The influence of iron content and calcination on phenol conversion over catalysts with potassium echange, $\mathrm{SxK}$ and $\mathrm{SxcK}$;

e) $\mathrm{pH}$ of reaction mixture in phenol oxidation over vermiculite-based Fe-doped catalysts;

f) the examples of post-reaction mixtures containing colored side-products.

short time intervals and again it was possible to convert substrate completely in less than 60 minutes. On the other hand, calcined samples after $\mathrm{K}^{+}$ion exchange SxKc (Fig. 6d) were less active. It could be concluded that optimum composition of the catalyst is necessary to obtain high efficiency of phenol removal. The excess of iron oxide, especially in the form of bulk species and big clusters do not enhance reaction. Moreover the higher Fe doping was used the more side-products were formed (Fig. 6f). Conversion of $\mathrm{H}_{2} \mathrm{O}_{2}$ in studied series of the catalysts $\mathrm{SxK}$ and $\mathrm{SxKc}$ is again lower for calcined materials. Taking into account obtained conversions, $\mathrm{K}^{+}$ion exchange seems beneficial for the samples with higher Fe loadings in non-calcined samples. On the contrary, potassium exchanged samples and calcined are less active then $\mathrm{K}^{+}$non-exchenged counterparts.

In each test the increase of conversion was followed by drop of $\mathrm{pH}$ of the reaction mixture to value equal 2 (Fig. 6e). This clearly indicates formation of acidic products (Bielicka-Daszkiewicz, 2008; Liotta et al., 2009).

\subsection{THE INFLUENCE OF STEPWISE ADDITION OF OXIDANT ON SUBSTRATE CONVERSION}

For selected catalyst additional tests were carried out in order to improve reaction efficiency. It was reported before that incomplete oxidation may result in formation of colored side-products such as hydroquinone, quinhydrone or even polymeric species 


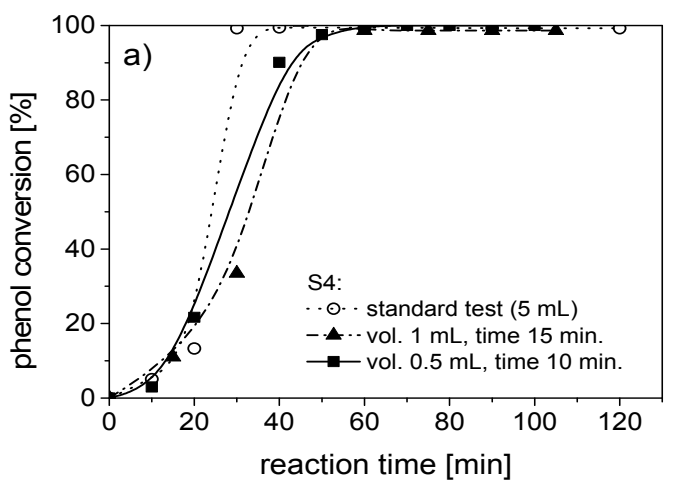

b)

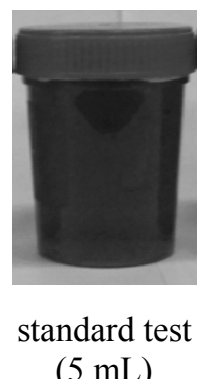

$(5 \mathrm{~mL})$

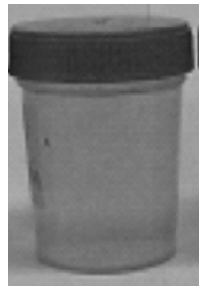

stepwise test (0.5 mL. $10 \mathrm{~min}$.

Fig. 7 a) The influence of the stepwise addition of oxidant on substrate conversion in phenol oxidation over vermiculite-based Fe-doped catalyst (phenol conversion;

b) formation of colored transition products during standard test and with stepwise addition of oxidant $\left(\mathrm{H}_{2} \mathrm{O}_{2}\right.$ volume $0.5 \mathrm{~mL}$, feeding ratio: 10 minutes - right) over Fe-doped vermiculite (S4).

(Alejandre et al., 1999). In standard test total volume of oxidant was added at the beginning of the reaction and as it was described above, significant amount of side products was observed. In alternative tests oxidant solution was added stepwise $(0.5$ or $1 \mathrm{~mL})$ in constant intervals (10 or 15 minutes). Conversion of phenol (Fig. 7a) was only slightly inhibited - time of a $50 \%$ was extended from 24 minutes to 28 or 33 , respectively. However at 60 minutes of the reaction total conversion of product was achieved. Moreover transparency of post-reaction mixture was significantly improved (Fig. 7b).

\subsection{CHARACTERIZATION OF SPENT CATALYSTS}

After catalytic reaction in XRD patterns (Fig. 8) significant changes were observed mostly in lower range of ${ }^{\circ} 2 \theta$. Basal reflections at $6.18^{\circ} 2 \theta$ became very sharp and intense (this phenomenon can be related to structural reconstruction), with an exception of the calcined sample with high $\mathrm{Fe}$ loading $\mathrm{S} 5 \mathrm{c}(\mathrm{r})$. Moreover, no peaks of hematite or feroxyhyte were detected in the sample S4(r) after reaction. Those two facts may indicate that during reaction part of iron oxide is dissolved and takes part in reaction in homogeneous phase as well as is intercalated between layers. Depending on reaction conditions Fe release measured in post-reaction mixtures was equal 1.1$7.7 \mathrm{mg}$ for the non-calcined samples (S4-S6) and 2.1$8.7 \mathrm{mg}$ for the calcined samples (S2Kc-S5Kc). In experimental conditions no leaching of $\mathrm{Fe}$ from the structure of non-modified vermiculites (S0-S0c) was detected.

Unclear is the origin of small peak at $8.55^{\circ} 2 \theta$ in the sample S4(r). On the other hand peaks at $18.56^{\circ}$, $24.85^{\circ}, 28.8^{\circ}$ and $31.2^{\circ} 2 \theta$ could be assigned to hydrobiotite. Interstratified phase was observed mostly for catalysts with low Fe doping. At higher Fe doping disappears also basal reflection assigned to 1 layer of water molecules. Basal spacings are presented in Table 5. Traces of iron oxides are notdetectable in spent catalyst $\mathrm{S} 4 \mathrm{c}(\mathrm{r})$, but characteristic peaks of hematite, traces of hydrobiotite and another phase, most probably muscovite, were observed for S5c(r) (Marcos et al., 2009; Marcos et al., 2010).

Leaching of $\mathrm{Fe}$ could be additionally confirmed using UV-Vis-DRS results (Fig. 9). In the case of non-modified vermiculites (calcined and noncalcined) there is no significant difference in peak positions, however it should be noted that in starting vermiculite (before calcination S0) dominating species are $\mathrm{Fe}$ isolated cations in tetrahedral coordination. On the contrary, in the calcined sample S0c ratio of octahedral $\mathrm{Fe}$ cations is higher. After reaction the opposite distribution may be observed - in the sample S0 cations in octahedral coordination are more numerous, but in the calcined sample - in tetrahedral.

As it was described in section 3.1., in the samples doped with iron (both calcined and noncalcined) isolated $\mathrm{Fe}$ cations are more likely to accommodate octahedral coordination. After catalytic reaction, in all samples, regardless calcination or $\mathrm{K}^{+}$ ion exchange, large number of isolated cations in tetrahedral coordination was observed. It results in the increase of relative intensity of peak at about $224 \mathrm{~nm}$. At the same time the decrease of relative peak intensity is observed for small $\mathrm{Fe}_{\mathrm{x}} \mathrm{O}_{\mathrm{y}}$ clusters as well as bulk iron oxide. Moreover, both peaks are shifted to lower wavenumbers (about 10-15 nm). The most extensive leaching of $\mathrm{Fe}$ was observed for noncalcined sample S4. Nevertheless, the precise and quantitative analysis of UV-Vis spectra may be hindered by significant change of hydration state of the studied samples.

Those facts are in an agreement with previous observations that interlayer space is strongly altered probably by $\mathrm{Fe}^{3+}$ cations released from introduced iron oxide. It cannot be excluded that, in minor proportion, $\mathrm{Fe}^{3+}$ cations were also introduced in the octahedral layers (Argüelles et al., 2011).

In presented studies only traces of organic compounds, possible reaction products, were identified using DRIFT technique (results not shown). As it was shown in section 3.3., all transition products have acidic character (Bielicka-Daszkiewicz, 2008, 


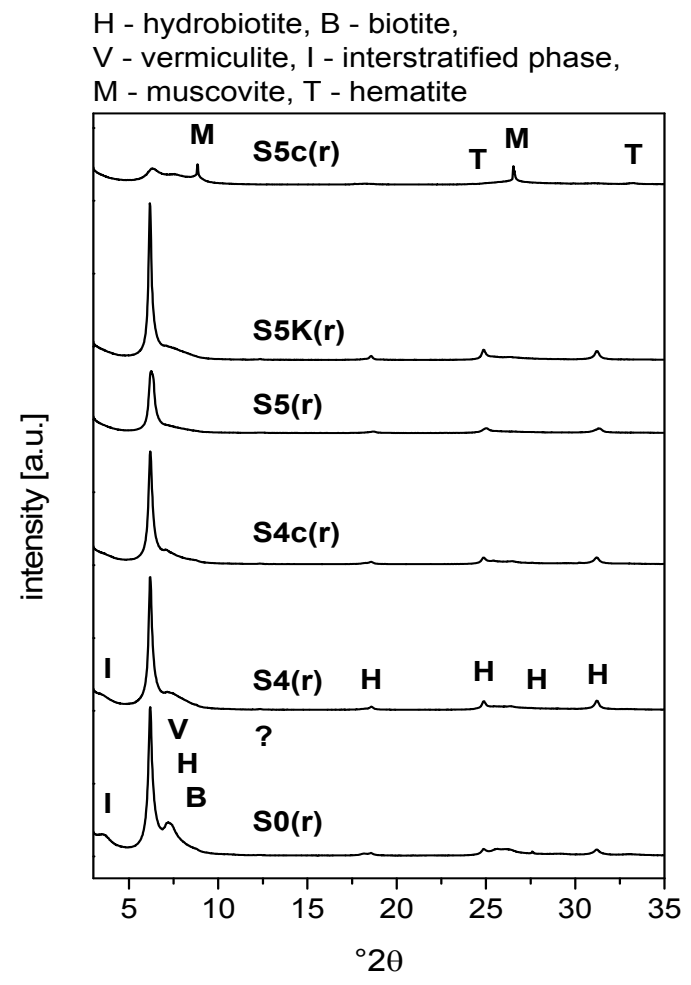

Fig. 8 XRD patterns of catalysts after reaction.

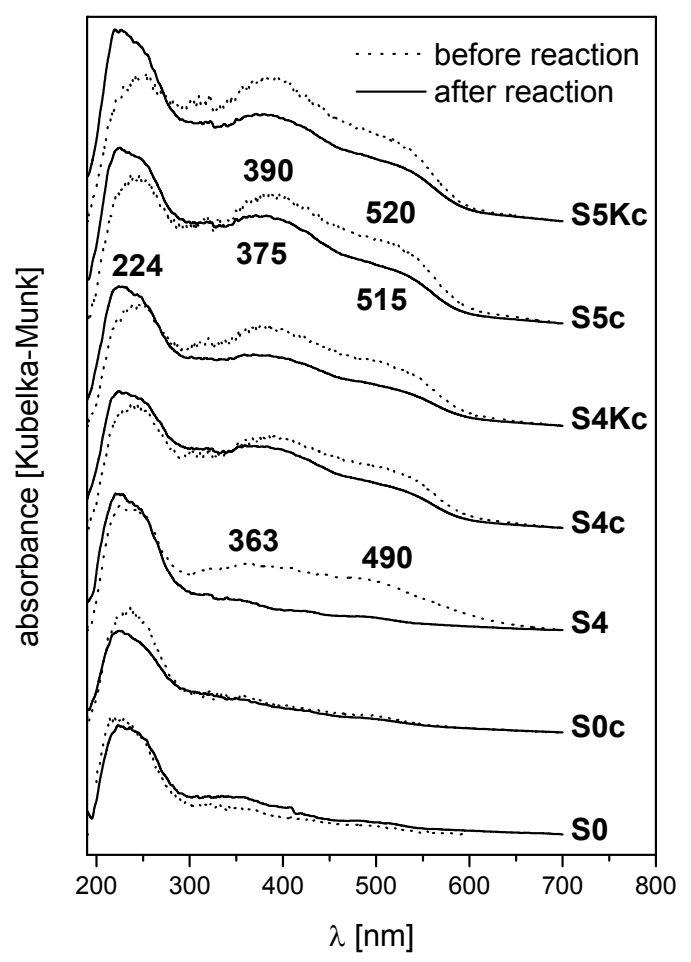

Fig. 9 UV-Vis-DRS spectra of catalysts after reaction.

Table 5 Interlayer distance of Fe-modified vermiculite-based catalysts after reaction.

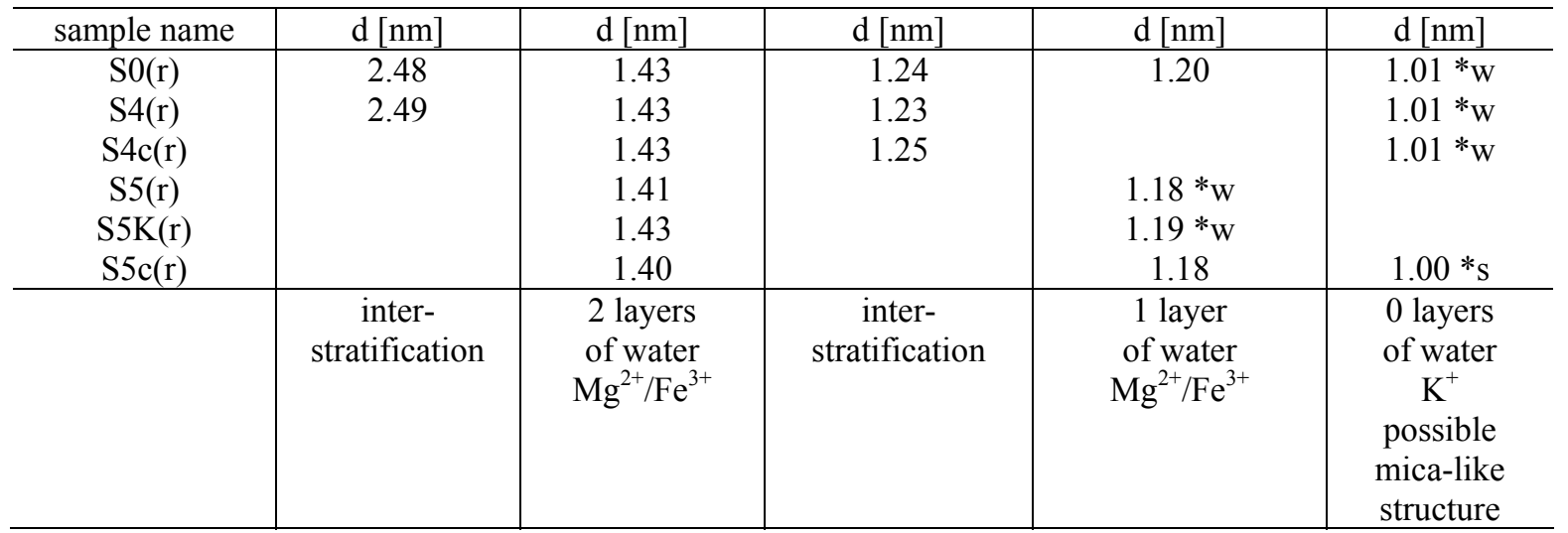

*w - weak, low intensity peaks, $\mathrm{s}-$ sharp peak

Liotta et al., 2009) and one cannot expect significant adsorption or its intercalation in interlayers.

\section{CONCLUSIONS}

In presented paper it was shown that vermiculites may be used as catalysts of phenol oxidation. The catalytic activity can be increased by additional doping with $\mathrm{Fe}$ compounds. Upon modification $\mathrm{Fe}$ cations were probably introduced into interlayer spaces and in minor proportion in octahedral layers, and metal oxide cluster are deposited on the surface. Depending on iron content four different species were identified: isolated cations in tetrahedral and octahedral coordination, small clusters of $\mathrm{Fe}_{\mathrm{x}} \mathrm{O}_{\mathrm{y}}$ and bulk $\mathrm{Fe}_{2} \mathrm{O}_{3}$. It was shown that the presence of isolated ions and small clusters is the most beneficial for the reaction efficiency. Optimum catalyst composition also allowed to avoid formation of large amounts of undesired side-products. Additionally those products could be avoided by stepwise addition of oxidant during reaction. Potassium exchange seems beneficial in the case of non calcined samples - $50 \%$ conversion was achieved in shorter time in comparison to their $\mathrm{K}$-non-exchanged counterparts. The opposite effect was observed in the case of calcined samples: potassium exchanged samples were characterized with lower conversions than non-exchanged catalysts. Characterisation of the spent catalysts revealed that partial degradation of deposited iron oxide may occur. Released $\mathrm{Fe}^{3+}$ cations occupied probably interlayer spaces and sites in octahedral layers and may play role of catalysts of the studied process. 


\section{ACKNOWLEDGEMENTS}

Authors acknowledge the Polish Ministry of Science for financial support in the frame of project NN 507 426939. The research was carried out with the equipment purchased thanks to the financial support of the European Regional Development Fund in the framework of the Polish Innovation Economy Operational Program (contract no. POIG.02.01.00-12023/08). Authors would like to thank Rominco Polska Sp. z o.o. for providing starting material for presented studies.

\section{REFERENCES}

Alejandre, A., Medina, F., Rodriguez, X., Salagre, P. and Sueiras, J.E.: 1999, Preparation and activity of $\mathrm{Cu}-\mathrm{Al}$ mixed oxides via hydrotalcite-like precursors for the oxidation of phenol aqueous solutions. Journal of Catalysis, 188, 311-324. DOI: 10.1006/jcat.1999.2625

Andreozzi, R., Caprio, V., Insola, A. and Marotta, R.: 1999, Advanced oxidation processes (AOP) for water purification and recovery. Catalysis Today, 53, 51-59. DOI: 10.1016/S0920-5861(99)00102-9

Argüelles, A., Khainakov, S.A., Rodríguez-Fernández, J., Leoni, M., Blanco, J.A. and Marcos, C.: 2011, Chemical and physical characterization of ironintercalated vermiculite compounds. Physics and Chemistry of Minerals, 38, 569-580.

DOI: 10.1007/s00269-011-0429-0

Barbier, J., Oliviero, L., Renard, B. and Duprez, D.: 2005, Role of ceria-supported noble metal catalysts $(\mathrm{Ru}, \mathrm{Pd}$, $\mathrm{Pt}$ ) in wet air oxidation of nitrogen and oxygen containing compounds. Topics in Catalysis 33, 77-86. DOI: $10.1007 / \mathrm{s} 11244-005-2509-1$

Bielicka-Daszkiewicz, K.: 2008, Usuwanie fenolu z wód ściekowych przez utlenianie (Removing phenol from wastewaters by oxidation). Przemysł Chemiczny, 87, 24-32, (in Polish).

Biń, A.K.: 1998, Zastosowanie procesów pogłębionego utleniania do uzdatniania wody, Ochrona Środowiska, 68, 3-6, (in Polish).

Busca, G., Berardinelli, S., Resini, C., Arrighi, L.: 2008, Technologies for the removal of phenol from fluid streams: A short review of recent developments, Journal of Hazardous Materials, 160, 265-288. DOI: 10.1016/j.jhazmat.2008.03.045

Carriazo, J., Guelou, E., Barrault, J., Tatibouet, J.M., Molina, R. and Moreno, S.: 2005, Catalytic wet peroxide oxidation of phenol by pillared clays containing Al-Ce-Fe. Water Research, 39, 3891-3899. DOI: 10.1016/j.watres.2005.06.034

Chen, Q., Wu, P., Dang, Z., Zhu, N., Li, P., Wu, J. and Wang, X.: 2010, Iron pillared vermiculite as a heterogeneous photo-Fenton catalyst for photocatalytic degradation of azo dye reactive brilliant orange X-GN. Separation and Purification Technology, 71, 315-323.

DOI: 10.1016/j.seppur.2009.12.017

Chmielarz, L., Kuśtrowski, P., Michalik, M., Dudek, B., Piwowarska, Z. and Dziembaj, R.: 2008, Vermiculites intercalated with $\mathrm{Al}_{2} \mathrm{O}_{3}$ pillars and modified with transition metals as catalysts of DeNOx process. Catalysis Today, 137, 242-246.

DOI: 10.1016/j.cattod.2007.09.009

Chmielarz, L., Kuśtrowski, P., Michalik, M., Dudek, B., Piwowarska, Z. and Dziembaj, R.: 2009, Natural micas intercalated with $\mathrm{Al}_{2} \mathrm{O}_{3}$ and modified with transition metals as catalysts of the selective oxidation of ammonia to nitrogen. Topics in Catalysis, 52, 1017-1022. DOI: $10.1007 /$ s11244-009-9263-8

Chmielarz, L., Kowalczyk, A., Michalik, M., Dudek, B., Piwowarska, Z. and Matusiewicz, A.: 2010, Acidactivated vermiculites and phlogophites as catalysts for the DeNOx process. Applied Clay Science, 49, 156-162. DOI: 10.1016/j.clay.2010.04.020

Chmielarz, L., Piwowarska, Z., Kuśtrowski, P., Wegrzyn, A., Gil, B., Kowalczyk, A., Dudek, B., Dziembaj, R. and Michalik, M.: 2011, Comparison study of titania pillared interlayered clays and porous clay heterostructures modified with copper and iron as catalysts of the DeNOx process. Applied Clay Science, 53, 164-173.

DOI: 10.1016/j.clay.2010.12.009

Chmielarz, L., Wojciechowska, M., Rutkowska, M., Adamski, A., Węgrzyn, A., Kowalczyk, A., Dudek, B., Boron, P., Michalik, M. and Matusiewicz, A.: 2012, Acid-activated vermiculites as catalysts of the DeNOx process. Catalysis Today, 191, 25-31. DOI: 10.1016/j.cattod.2012.03.042

Crini, G.: 2006, Non-conventional low-cost adsorbents for dye removal: A review. Bioresource Technology 97, 1061-1085. DOI: 10.1016/j.biortech.2005.05.001

Downs, R.T.: 2006, The RRUFF Project: an integrated study of the chemistry, crystallography. Raman and infrared spectroscopy of minerals. Program and Abstracts of the 19th General Meeting of the International Mineralogical Association in Kobe, Japan. O03-13.

Dukkanc1, M., Gunduz, G., Y1lmaz, S. and Prihod'ko, R.V.: 2010, Heterogeneous Fenton-like degradation of Rhodamine $6 \mathrm{G}$ in water using CuFeZSM-5 zeolite catalyst prepared by hydrothermal synthesis. Journal of Hazardous Materials, 181, 343-350. DOI: 10.1016/j.jhazmat.2010.05.016

Feng, J., Hu, X. and Yue, P.L.: 2006, Effect of initial solution $\mathrm{pH}$ on the degradation of Orange II using clay-based $\mathrm{Fe}$ nanocomposites as heterogeneous photo-Fenton catalyst. Water Research, 40, 641-646. DOI: 10.1016/j.watres.2005.12.021

Galeano, L.A., Vicente, M.A. and Gil, A.: 2011, Treatment of municipal leachate of landfill by fenton-like heterogeneous catalytic wet peroxide oxidation using an $\mathrm{Al} / \mathrm{Fe}$-pillared montmorillonite as active catalyst. Chemical Engineering Journal 178, 146-153. DOI: $10.1016 /$ j.cej.2011.10.031

Garrido-Ramírez, E.G., Theng, B.K.G. and Mora, M.L.: 2010, Clays and oxide minerals as catalysts and nanocatalysts in Fenton-like reactions - A review. Applied Clay Science, 47, 182-192. DOI: $10.1016 /$ j.clay.2009.11.044

Helsen, J.A.: 1975, The orientation of the principal axes system of the electric field gradient in $\mathrm{Fe}$ (III) vermiculite determined by Mössbauer spectroscopy. Clays and Clay Minerals, 23, 332-334. DOI: 10.1346/CCMN.1975.0230411

Hocevar, S., Krasovec, U.O., Orel, B., Arico, A.S. and Kim, H.: 2000, CWO of phenol on two differently prepared $\mathrm{CuO}-\mathrm{CeO} 2$ catalysts. Applied Catalysis B: Environmental, 28, 113-125. DOI: 10.1016/S09263373(00)00167-3

Iurascu, B., Siminiceanu, I., Vione, D., Vicente, M.A. and Gil, A.: 2009, Phenol degradation in water through a heterogeneous photo-Fenton process catalyzed by $\mathrm{Fe}-$ treated laponite. Water Research, 43, 1313-1322. DOI: 10.1016/j.watres.2008.12.032 
Kim, S.K., Kim, K.H. and Ihm, S.K.: 2007, The characteristics of wet air oxidation of phenol over $\mathrm{CuOx} / \mathrm{Al} 2 \mathrm{O} 3$ catalysts: effect of copper loading. Chemosphere 68, 287-292. DOI: $10.1016 /$ j.chemosphere.2006.12.080

Kim, K-H. and Ihm, S-K.: 2011, Heterogeneous catalytic wet air oxidation of refractory organic pollutants in industrial wastewaters: A review. Journal of Hazardous Materials, 186, 16-34. DOI: $10.1016 /$ j.jhazmat.2010.11.011

Ledakowicz, S., Olejnik, D., Perkowski, J. and Żegota, H.: 2001, The use of advanced oxidation processes (AOP) for the decomposition of Triton X-114 nonionic detergent. Przemysł Chemiczny, 80/10, 453-459.

Liotta, L.F., Gruttadauria, M., Di Carlo, G., Perrini, G. and Librando, V.: 2009, Heterogeneous catalytic degradation of phenolic substrates: Catalysts activity. Journal of Hazardous Materials, 162, 588-606. DOI: 10.1016/j.jhazmat.2008.05.115

Liu, D., Yua, P., Liu, H., Cai, J., Qin, Z., Tan, D., Zhou, Q., He, H. and Zhu, J.: 2011, Influence of heating on the solid acidity of montmorillonite: A combined study by DRIFT and Hammett indicators. Applied Clay Science, 52, 358-363.

DOI: $10.1016 /$ j.clay.2011.03.016

Luck, F.: 1996, A review of industrial catalytic wet air oxidation processes. Catalysis Today, 27, 195-202. DOI: 10.1016/0920-5861(95)00187-5

Luck, F.: 1999, Wet air oxidation: Past, present and future. Catalysis Today, 53, 81-91. DOI: $10.1016 /$ S0920-5861(99)00112-1

Magario, I., García Einschlag, F.S., Rueda, E.H., Zygadlo, J. and Ferreira, M.L.: 2012, Mechanisms of radical generation in the removal of phenol derivatives and pigments using different Fe-based catalytic systems. Journal of Molecular Catalysis A: Chemical, 352, 120. DOI: 10.1016/j.molcata.2011.10.006

Marcos, C., Arango, Y.C. and Rodriguez, I.: 2009, X-ray diffraction studies of the thermal behavior of commercial vermiculites. Applied Clay Science, 42, 368-378. DOI: 10.1016/j.clay.2008.03.004

Marcos, C. and Rodríguez, I.: 2010, Expansion behaviour of commercial vermiculites at $1000{ }^{\circ} \mathrm{C}$. Applied Clay Science, 48, 492-498. DOI: $10.1016 /$ j.clay.2010.02.012

Massa, P., Ivorra, F., Haure, P., Cabello, F.M. and Fenoglio, R.: 2007, Catalytic wet air oxidation of phenol aqueous solutions by $1 \% \mathrm{Ru} / \mathrm{CeO}_{2}-\mathrm{Al}_{2} \mathrm{O}_{3}$ catalysts prepared by different methods. Catalytic Communications, 8, 424-428.

Matta, R., Hanna, K. and Chiron, S.: 2007, Fenton-like oxidation of 2,4,6-trinitrotoluene using different iron minerals, Science of the Total Environment, 385, 242251. DOI: $10.1016 /$ j.scitotenv.2007.06.030

Navalon, S., Alvaro, M., Garcia, H.: 2010, Heterogeneous Fenton catalysts based on clays, silicas and zeolites. Applied Catalysis B: Environmental, 99, 1-26. DOI: $10.1016 /$ j.apcatb.2010.07.006

Ramirez, J.H., Costa, C.A., Madeira, L.M., Mata, G., Vicente, M.A., Rojas-Cervantes, M.L., LopezPeinado, A.J. and Martin-Aranda, R.M.: 2007, Fentonlike oxidation of Orange II solutions using heterogeneous catalysts based on saponite clay. Applied Catalysis B: Environmental, 71, 44-56. DOI: $10.1016 /$ j.apcatb.2006.08.012
Rivas, F.J., Kolaczkowski, S.T., Beltran, F.J. and McLurgh, D.B.: 1999, Hydrogen peroxide promoted wet air oxidation of phenol: influence of operating conditions and homogeneous metal catalysts. Journal of Chemical Technology and Biotechnology, 74, 390398. DOI: 10.1002/(SICI)1097-4660(199905)74:5<390::AIDJCTB64>3.0.CO, 2-G

Rokhina, E.V. and Virkutyte, J.: 2011, Environmental application of catalytic processes: Heterogeneous liquid phase oxidation of phenol with hydrogen peroxide. Critical Reviews in Environmental Science and Technology, 41, 125-167. DOI: $10.1080 / 10643380802669018$

Soon, A.N. and Hameed, B.H.: 2011, Heterogeneous catalytic treatment of synthetic dyes in aqueous media using Fenton and photo-assisted Fenton process. Desalination, 269, 1-16. DOI: $10.1016 /$ j.desal.2010.11.002

Steudel, A., Batenburg, L.F., Fischer, H.R., Weidler, P.G. and Emmerich, K.: 2009, Alternation of swelling clay minerals by acid activation. Applied Clay Science, 44, 105-115. DOI: 10.1016/j.clay.2009.02.002

Tabet, D., Saidi, M., Houari, M., Pichat, P. and Khalaf, H.: 2006, Fe-pillared clay as a Fenton-type heterogeneous catalyst for cinnamic acid degradation. Journal of Environmental Management, 80, 342-346. DOI: $10.1016 /$ j.jenvman.2005.10.003

Tomaszewska, A.: 2009, Reakcja Fentona w podczyszczaniu ścieków farmaceutycznych. Przegląd Techniczny, 5-6, XVIII-XIX, (in Polish).

Węgrzyn, A., Rafalska-Łasocha, A. and Dziembaj, R.: 2006, Adsorption of humic acids and phenol from aqueous solution using hydrotalcite-derived mixed metal oxides - competition between different anionic species. XIII Polish Zeolite Forum, Polańczyk, 259264.

Węgrzyn, A., Knihnicki, P., Mitoń, A., Majda, D. and Dziembaj, R.: 2007, Adsorption of polar (phenol) and non-polar (toluene) organic molecules on hydrotalcitederived mesoporous materials. XIV Polish Zeolite Forum, Kocierz, 229-234.

Wu, Q., Hu, X., Yue, P.L., Zhao, X.S. and Lu, G.Q.: 2001, Copper/MCM-41 as catalyst for the wet oxidation of phenol. Applied Catalysis B: Environmental, 32, 151156. DOI: $10.1016 / \mathrm{S} 0926-3373(01) 00131-X$

Xu, H.-Y., Prasad, M. and Liu, Y.: 2009, Schorl: A novel catalyst in mineral-catalyzed Fenton-like system for dyeing wastewater discoloration. Journal of Hazardous Materials, 165, 1186-1192. DOI: 10.1016/j.jhazmat.2008.10.108

Xu, L. and Wang, J.: 2011, A heterogeneous Fenton-like system with nanoparticulate zero-valent iron for removal of 4-chloro-3-methyl phenol. Journal of Hazardous Materials, 186, 256-264. DOI: $10.1016 /$ j.jhazmat.2010.10.116 